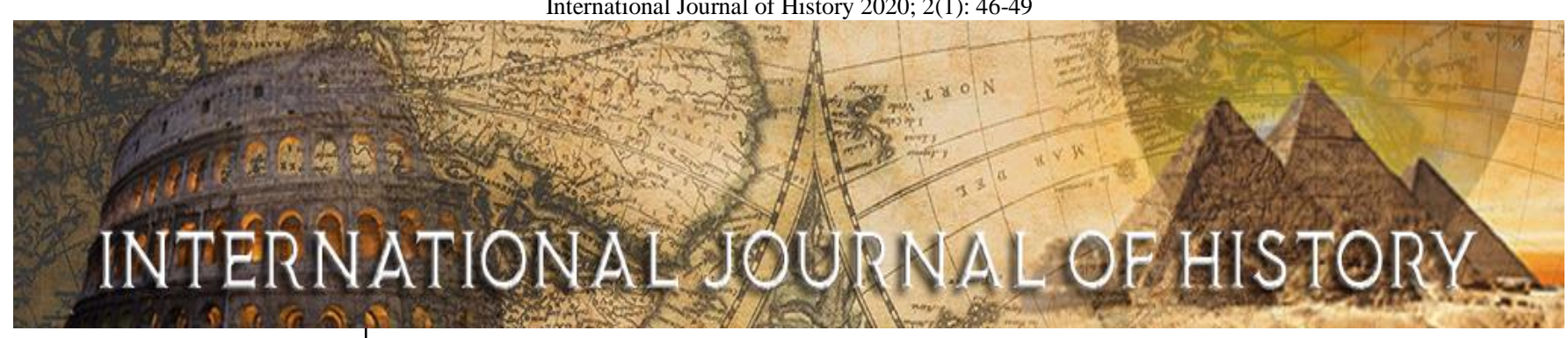

E-ISSN: 2706-9117 P-ISSN: 2706-9109 IJH 2020; 2(1): 46-49 Received: 17-02-2020 Accepted: 19-03-2020

Dr. Subhash Chandra Prasad Assistant Professor (History), Guest Faculty, Ramautar Gautam Sanskrit College, Ahalyasthan, Darbhanga, K.S.D.S.U., Darbhanga Bihar, India
Corresponding Author: Dr. Subhash Chandra Prasad Assistant Professor (History), Guest Faculty, Ramautar Gautam Sanskrit College, Ahalyasthan, Darbhanga, K.S.D.S.U., Darbhanga Bihar, India

\section{Relevance of the teaching's of Gurunanak today}

\section{Dr. Subhash Chandra Prasad}

DOI: $\underline{\text { https://doi.org/10.22271/27069109.2020.v2.i1a.37 }}$

\begin{abstract}
Guru Nanak, the great proponent of 15th-century humanism at the theater of Indian history, is considered an ideal of mutual harmony. He devoted his entire life to promoting harmony among people of different religions. Unlike an ordinary man, from his boyhood, Nanak began to find a unique way of bridging the gaps between the true meaning of life and the followers of different religions. His teachings form the basement of Sikhism and he is considered the first Guru of the Sikh religious tradition. The main objective of Guru Nanak's teachings can be said to be an attempt to establish world peace by ending communal conflicts. A task that he himself wanted to complete throughout his life. Through this article an attempt has been made to find out the relevance of the teachings of Guru Nanak Dev Ji which can guide towards a harmonious society.
\end{abstract}

Keywords: Preachers, devotion, spiritual, gurumukhi, divine, nirakar brahma, soul

\section{Introduction}

Guru Nanak, was a great advocate of humanism of India. He was considered as the model of interreligious harmony. He dedicated his whole life to promote harmony among the people of different faiths. Unlike an ordinary man, from his boyhood Nanak started to search for the true meaning of life and a way to bridge the gaps among the followers of different religions. His teachings form the basement of Sikhism and he is regarded as the first Guru of the Sikh religious tradition. The teachings of Guru Nanak can be termed as the model for establishing universal peace by eliminating communal conflicts-a task which he himself wanted to accomplish throughout his whole life.

Guru Nanak is known for his political, social and spiritual beliefs, which were based on love, equality, fraternity and virtue. He traveled to far off places and spread the message of 'one God' and God constitutes the eternal truth and he resides in his creations.

\section{Main Text}

Sikhism emerged in the course of the Bhakti movement of medieval northern India. Its founder was Guru Nanak. He was born in 1469 AD at a place called Talwandi in western Punjab. He propagated monotheism based on Nirguna Bhakti and opposed discrimination between humans on the basis of religion, caste, birth and family. He also contradicted religious rituals and outward manners and laid special emphasis on reverence for God and pure moral conduct. After Guru Nanak, Angad became the Guru of Sikhs and after him Amardas and Ramdas became Guru. By the time of Ramdas, the Sikhs became a separate religious sect. The Sikhs considered their guru an incarnation of God. Ramdas's life was so pure and simple that Akbar donated 500 bighas of land to him, on which he built a pond and a temple in Amritsar. Ramdas then proclaimed his son Arjuna as the successor. With this, the post of Guru became hereditary ${ }^{[1]}$.

According to the 1981 census in India, the number of Sikhs is about 10 million. It is two percent of the population of India. And thus their number in itself is quite small. Northern India, especially Punjab, is the principal residence of Sikhs, but these people are spread in all the states of India and due to their hard work and courage, they have made a special contribution to the progress and prosperity of the country. A large number of Sikhs have migrated out of the country and settled in other countries, where they have made an important place. In comparison, Sikhism can be said to be quite modern, because the foundation of this religion was laid by Guru Nanak Dev 500 years ago. Guru Nanak Dev was a reformist preacher and opposed the religious and social practices prevalent at that time. 
His basic principles were - unwavering faith in the power of God, good work and fraternity should be the ideal of man. He directly exposed the deep secrets of God and creation in simple terms, and also explained how man can attain salvation by rising above the worldly bonds through the development of soul. These core principles of Guru Nanak became the source of inspiration for the education and initiation of the later gurus. This principle is the basis of Sikh ideology.

During the time of Guru Nanak, Bhakti movement and Sufiism had spread in the cultural background of India. Guru Nanak ji preached about the unity of God, mutual brotherhood and service of mere beings. He refuted the orthodox customs, superstitions and religious fetters and raised his voice against the ongoing injustice on the basis of caste. He traveled to far-flung countries and was always accompanied by two companions, a Muslim-Mardana and a Hindu - on these trips. He said that all are equal before that God, neither is there any upper caste nor any lower caste ${ }^{[2]}$. The Sikh sect was formed during the Mughal rule. Nanak was one of the preachers of the Bhakti - Marg. The Bhaktimovement, which was a major feature of the medieval religious life, also influenced Punjab. Guru Nanak was one of the great saints who believed in the similarities of both Hindu and Muslim religions and tried to bring Hindus and Muslims closer to each other. Punjab remained a prominent place in his field of work, though he also traveled all over India and countries outside India. Guru Nanak did not establish any new religious sect. He did not write any religious book nor did he try to make any place a religious place. He had made only disciples who later became known as 'Sikhs'. On the occasion of his death, Nanak chose Angad, who became the second Guru of the Sikhs, to propagate his ideas. Guru Nanak was a contemporary of Emperor Babur and Humayun ${ }^{[3]}$.

Preachers of Bhakti spirit and social reformer saints whose focus was on removing religious and social evils were Guru Nanak. Nanak got his primary education in his village school. Right from childhood, he was anxious and used to enjoy thinking about the problems of life and death. His father married him to a Khatri girl so that his mind would become engaged in household life. But even this did not affect Nanak's brain. After some time Nanak was also sent to his brother to learn the work. Jai Ram, the father of Nanak, was at this time a grain merchant in the service of Daulat Khan Lodi in Sultanpur. Nanak was not interested in keeping the books, so he quit his job and started spending time in the company of sadhus. At the age of thirty, he traveled around the country and abroad in disguise of the monk. He discussed with many saints and gained knowledge about other religions. Like Kabir, Nanak was also a householder. But still he spent more and more time in cultivation, devotion and preaching. His household life never proved to be a hindrance in his spiritual progress.

Nanak was a well-educated man. In addition to his mother tongue Gurmukhi, he also had a good knowledge of Persian and Hindi. His religious outlook became very wide as he came into contact with religions and beliefs prevalent in India, Central Asia and Arabia. He attracted the attention of the people by saying 'no Hindu and no Muslim'. He believed in monotheism like Muslims. Hindu religion, Islam religion, Yogis and Sufimat etc. had particular influence on them. He said that God has sent him to perform an important and divine work and that is to establish unity between Hindus and Muslims, remove the evils of both religions and end religious disharmony. Like Muhammad, he also said that God is one - only one, and he is the messenger of God.

The God of Nanak was inexplicable, inaccessible, ignorant, continuous, casteless, immortal, indolent, independent, having millions and crores of form and shape, but was completely different from his own created creation. He is formless, unique, amazing and whose knowledge is beyond the senses. He is omnipresent, omnipotent, omniscient and pervading the whole world. He is present in every particle and in it there is the whole world. Like Muhammad Sahab, Guru Nanak preached to his worshipers to surrender to God. He praised the good qualities of human beings and denied the evils arising in them. He particularly emphasized on following the Middle Way. He did not believe in rebirth traffic. He said that the deeds of karma will continue to be unhappy and will not be free from traffic until they take the path of truth and goodness. He preached his worshipers to behave politely, to renounce ego, to control the senses, to meditate on God, to be free from work and to walk on the path of truth. In his teachings, morality, truth, charity, mercy were prominent. He emphasized loving devotion to God.

Like Sufi saints, Nanak also believed that the union of God with the soul required the help of the home. Without a Guru, neither one can attain knowledge nor can one complete this journey alone. Like Kabir, Nanak also did not believe in Vedas, Quran, Puran etc. But still this book remained the source of his spirituality. The religious texts of the Hindus were based on popular beliefs and their personal practice and experience based on their philosophical and religious views. At that time there was the prominence of caste, idol worship, fasting, religious ceremonies, Brahmins and clerics in the society. He openly opposed all this. He made Muslims, untouchables and Hindus his disciples and he did not discriminate against any kind. His works were compiled in the Adi Granth.

Nanak never thought of establishing a new religion. Their aim was to reform Hinduism only on the basis of the belief of God, give it new power and increase the feeling of brotherhood among Hindu-Muslims. His ideals and ideas had an impact on Hindu-Muslim society. He gained fame among both Hindus and Muslims. The only reason for this was that he tried to integrate the ideologies of all religions and faiths ${ }^{[4]}$.

His son Srichand established the "Udeseen" sect which follows the religious guidelines of Sanatan Dharm. "Guru Granth Saheb" is the book of Sikh religion which is a collection of the sayings of Nanak and its other Sikh Masters. Nanak talked about nirakar brahm but he never told the dry gyan; he stressed upon bhakti and gyan both, although his bhakti was not the real affectionate bhakti as described by the Vaishnav acharyas ${ }^{[5]}$.

Nearly 400 years before the birth of Guru Nanak, India suffered from the invasion of foreigners. The people had left their spiritual treasury and lost the power of united action and defense as a result. Furthermore, they were divided into castes and classes at war with each other. The rulers were corrupt. The weakness of the Lodis was a sign of Babur's invasion.

Hindus faced political slavery and many of them were forced to embrace Islam. Learning was limited to Brahmins; The people of the middle and lower classes were held in a wall of ignorance, poverty and superstition. On the other hand, the upper-class Hindus exploited the Shudras and the 
untouchables in the same way as the Muslims. He further accelerated the decline of Hindu society by the tyranny of caste rules. Women were insulted and abused.

Although Muslims were comparatively superior to Hindus, they were also unhappy. Their rulers were corrupt and ineffective. He propagated his faith and his political views at the point of the sword. The situation of Muslim women was not satisfactory. Melfol regarded them as objects of sexual gratification and treated them accordingly. They were disbelieved and confined within the four walls and placed under purdah. The practice of female feticide was prevalent in the community. Even sati practice was not unknown in Muslim families. Guru Nanak was born at an important period in Indian history. Guru Nanak says, "Age is a dagger, rulers are butchers". Religion has given rise to darkness of lies and lies. Undoubtedly, there were signs of the light and brightness of the Renaissance in the emergence of Namdev, Chaitanya, Kabir, Surdas.

Guru Nanak taught people courage, discipline and selfrespect, showing how man can live the Dharma in daily life and awaken people to the meditation of God through the practice of Naam. At the age of 38, in August 1507, Guru Nanak heard the call of God to dedicate himself to the service of humanity. The first sentence he spoke was, "There is no Hindu, no Muslim." He now thought of visiting various countries to propagate his theory. During the first visit, Guru Nanak visited Aminabad and converted Malik Bhago. The Guru refused to be a part of Malik Bhago's feast, as his income came from the exploitation of others. He went to Haridwar, where he threw water in the western direction, convincing people to offer a gem to the souls of his ancestors. Then he went to Banaras, Gaya in the east and finally to Kamrup (Assam). He then moved south to Delhi via Puri and Rameswaram and then back to Dwarika. He visited Kurukshetra at the time of the fair and gave his message to the pilgrims.

During the second journey, Guru Nanak went to Sialkot and proceeded further north to Mount Sumeru via Srinagar. There he met the Siddhas, whom he preached to the Grista Ashram and the value of meditation. From there he returned to Kartarpur, the Guru's home.

Guru went west during the third journey. He visited the Karachi region and stayed at the place where the Akal Bunga Gurudwara is now. Then Guru went to Surat and from there to Mecca. In Mecca, he converted the priest by showing that God's place is in all directions, and not just in the west. Then Guru went to Medina and thereafter to Baghdad. At this time, Babur attacked India and there was a lot of mass murder of common citizens in Eminabad. Guru Nanak went to Babur and got the prisoners released. He saved the people from sorrow and bloodshed ${ }^{[6]}$.

Guru Nanak was the re-awakening of the principle of pure monotheism of the Upanishads. Like Kabir, he also preached monotheism, condemned idol worship, opposed multi-god worship and resisted the rituals of Hindus and Muslims. Guru Nanak was a coordinating saint whose purpose was to end the conflict of various religions. Guru Nanak was opposed to the caste system, just like Kabir. He said that the light of God is in all persons and there is no caste difference in him. To be proud of the superiority of caste is to turn away from God. Nanak was a coordinating saint whose purpose was to end the conflict of various religions. Like Kabir, Nanak contradicted the superstitions that had entered into both Hindus and Muslims. Guru Nanak emphasized on making life high by following the best ideals of honesty, trustworthiness, truth-loyalty, charity, kindness, prohibition, etc. He preached everywhere on the ubiquity of God. Full of god. Stating that the spirit of self-surrender is the means of salvation, he did not say that it is necessary to renounce the world by abandoning the world in the eyes of God, he meant to say that religious monks and devotees and householders are all the same. Like Kabir, Nanak expressed disbelief in the Vedas and idolatry. He considered the attainment of salvation by surrender at the feet of Almighty God. Nanak expressed faith in the doctrine of karma and rebirth ${ }^{[7]}$.

The main themes of Guru Nanak's teachings are Kirat, Kudrat and Gian i.e. manual work, respect for nature, and knowledge. All of these aspects are interwoven. Though Guru Nanak was seen as a mystic, he didn't believe in or prach withdrawal from life and the world. He was against the practices of yogis and sidhas, who withdrew from real life. He was a keen observer and took deep interest in social, cultural and religious problems that the people of that time were facing. His hymns oppose casteism and exploitation, and preach equality, brotherhood, truthful living, social responsibilities and social justice.

His second main concern, along with active manual work (Kirat) in society, was respect for nature. He recognized that all creatures are part and parcel of Nature, and are dependent upon each other. So he said, "Pavan Guru, Pani Pita, Mata Dharat Mahat" (Air is a great teacher, water is like father and Earth is our beloved mother). Water is so essential that we can't think to live without it ("Pehal Pani Jio Hai") ${ }^{[8]}$.

Guru Nanak was one of the greatest religious innovators of all time and the founder of the Sikh religion. Nanak's religious ideas draw on both Hindu and Islamic thought, but are far more than just a synthesis. Nanak was an original spiritual thinker and expressed his thoughts in extraordinary poetry that forms the basis of Sikh scripture ${ }^{[9]}$.

\section{Conclusion}

In a world that is increasingly fragmented with a narrow vision, bigotry and dogmatism, we have to walk on the path shown to us by Nanak and other illustrious gurus to dispel the darkness that constantly threatens to envelop individuals, communities and nations.

Relevance of the teachings of Guru Nanak Dev Ji are required to be imbibed among present-day Indian society. With sustained efforts by all stakeholders, especially the media, the cherished ideas of egalitarianism of Guru Nanak Ji could be the true outcome.

The world needs such spiritual leaders who can engage in a meaningful dialogue to exchange ideas in order to promote peace, stability and cooperation.

\section{References}

1. अहमद, इम्तियाजः "मध्यकालीन भारत का संक्षिप्त इतिहास", जेनरल बुक एजेन्सी, पटना, संस्करण, 1991, 168

2. रणधीर सिंह, गुरुबख्शः "भारत के गुरुद्वारे", तारा आर्ट प्रेस, बहादुरशाह जफर मार्ग, हंस भवन, नई दिल्ली, संस्करण, 1993, 1-2

3. शर्मा, एल.पी.: "मध्यकालीन भारत", लक्ष्मीनारायण अग्रवाल, संशोधित संस्करण- 2004, 141

4. गुप्त, शिवकुमार: "मध्यकालीन भारत का इतिहास", पंचशील प्रकाशन, जयपुर, संस्करण, 1999, 295-96

5. Saraswati, Prakashnand Swami: "The True History and the Religion of India", Motilal Banarsidass Publishers 
Pvt. Ltd., First Indian Edition, Delhi, 644.

6. Chandra, Ramesh: "Religions of India", Commonwealth Publishers, Darya Ganj, New Delhi, First Published, 2004, 49-50

7. सिंह, प्रताप: "ऐतिहासिक निबंध", रिसर्च पब्लिकेशन्स, जयपुर/नई दिल्ली, 209-10

8. https://cpiml.net/liberation/2019/12/relevance-of-gurunanak-devs-teachings-to-society-today

9. https://www.bbc.co.uk/religion/religions/sikhism/peopl e/nanak.shtml. 